Contribution 1983-1E

\title{
Growth habit and control of wild oats
}

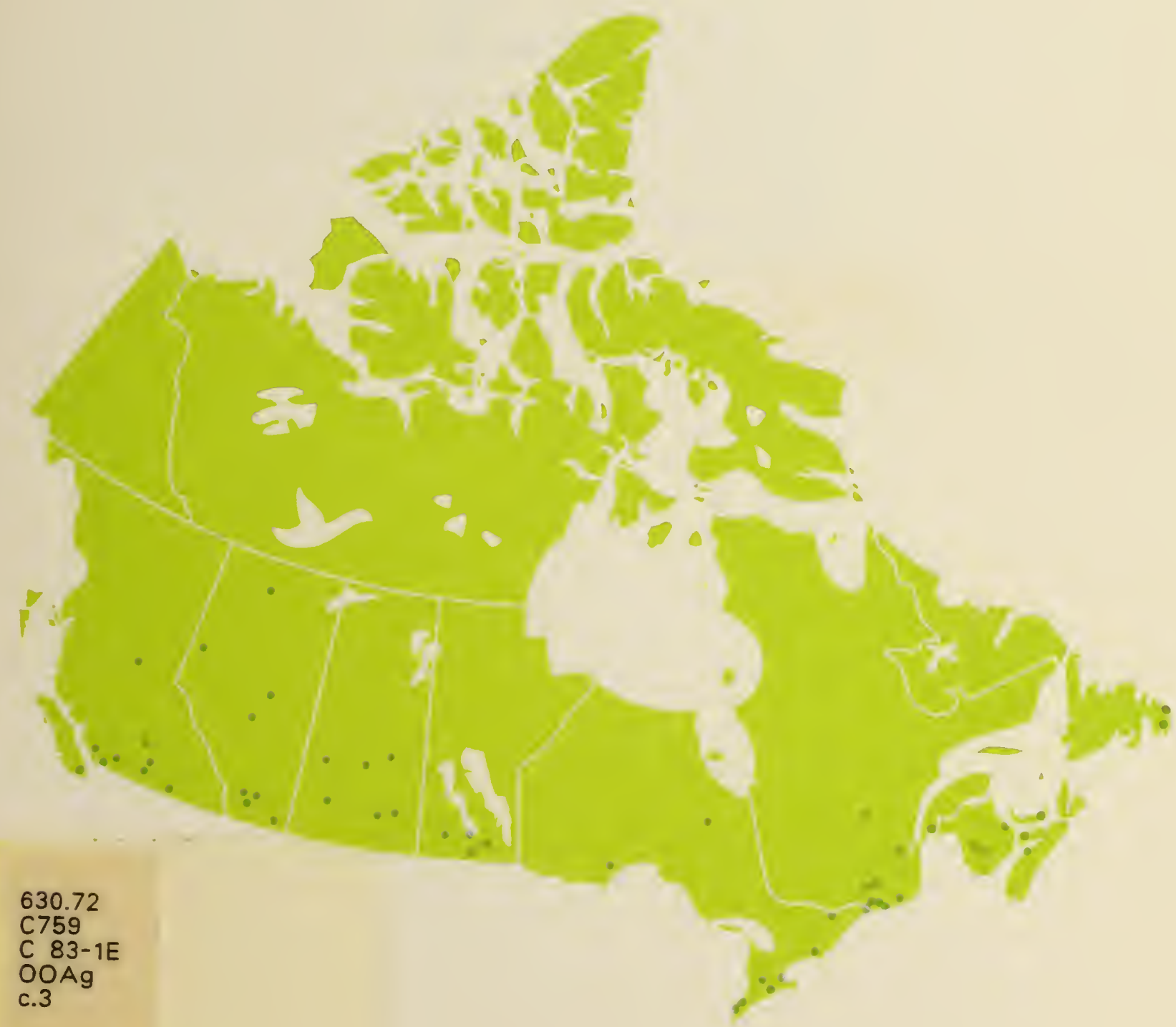


The map on the cover has dots representing

Agriculture Canada research establishments.

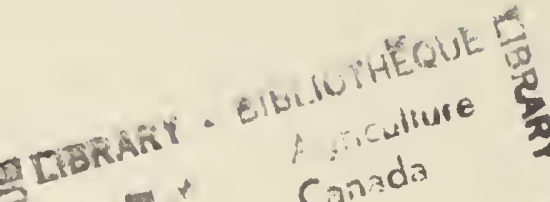

III Canada

9 DepartMENTAL LIGRART

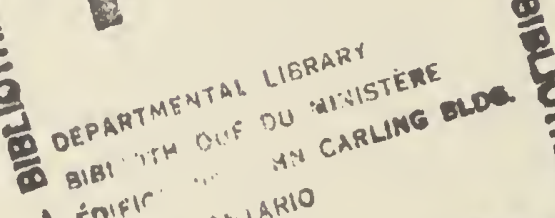

- Eorfir ora ontario

Kia OCD

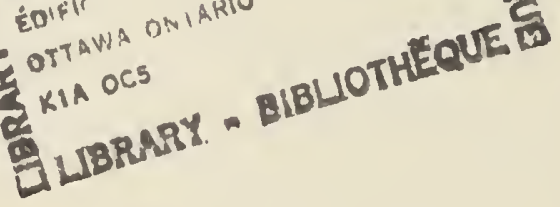




\section{Growth habit and control of wild oats}

Revised by C. J. BIBAR from the original by J.D. BANTING

Research Station

Regina, Saskatchewan

Research Branch

Agriculture Canada

1983 
Coppes of this publication ase asailable from

C. J. Bubar

Reseasch Station

Research Branch, Agriculume Canada

Regina, Sashaltchewan

SIP $3: 12$

Picklacel by Reseanch Program Service

Mumser of Supply and Services Canada 1983 


\section{SUMMARY}

Wild oat remains one of the most serious weed problems in western Canada. Virtually every hectare of land planted to cereal and oilseed crops is treated with a wild oat herbicide. The persistence of wild oat may be ascribed to the many survival mechanisms inherent in its unique growth habit. Therefore the weed continues to cause substantial yield losses which vary according to the crop species, fertility level, environmental conditions, the number of wild oats present and the time of emergence and removal of wild oats. Although it is almost impossible to eliminate wild oats completely, they can be kept to a low level in crops through the use of a combination of control measures. This technical bulletin outlines the growth habit, potential crop losses as well as the agronomic practices, cultural control methods and herbicides that may be used to combat wild oats.

\section{Résumé}

La folle avoine demeure l'un des plus graves problèmes de mauvaises herbes dans I'ouest du Canada. Chaque hectare de terre semé en céréales et oléagineux doit être virtuellement traité à l'herbicide. La persistance de cette mauvaise herbe peut être attribuée aux nombreux mécanismes de survie inhérents à son mode de développement unique. Elle continue donc à causer des pertes de rendement substantielles qui varient selon les espèces cultivées, le taux de fertilité du sol, les conditions du milieu, la population de folle avoine, ainsi que l'époque de la levée et de l'élimination de la mauvaise herbe. Bien qu'il soit pratiquement impossible de l'éliminer complètement, il est possible d'en maintenir la densité à un faible niveau dans les cultures par une combinaison de moyens de lutte. Ce bulletin technique décrit le mode de développement, les pertes de récolte potentielles, ainsi que les pratiques agronomiques, méthodes de lutte culturales et herbicides qui peuvent servir à combattre la folle avoine. 


\section{Digitized by the Internet Archive}

in 2013 


\section{CONIENTS}

INTRODUCTION $\ldots \ldots \ldots \ldots \ldots \ldots \ldots \ldots \ldots \ldots \ldots \ldots \ldots \ldots \ldots$

SURV IVAL MECHANISMS $\ldots \ldots \ldots \ldots \ldots \ldots \ldots \ldots \ldots \ldots \ldots$

Dormancy ................................. 1

Germination $\ldots \ldots \ldots \ldots \ldots \ldots \ldots \ldots \ldots \ldots \ldots \ldots \ldots \ldots \ldots \ldots \ldots \ldots$

Physical Structure $\ldots \ldots \ldots \ldots \ldots \ldots \ldots \ldots \ldots \ldots \ldots$

Regrowth and Rerooting .....................

Early Maturity $\ldots \ldots \ldots \ldots \ldots \ldots \ldots \ldots \ldots \ldots \ldots \ldots \ldots$

Uneven Ripening $\ldots \ldots \ldots \ldots \ldots \ldots \ldots \ldots \ldots \ldots \ldots$

POTENTIAL LOSSES FROM WILD OATS ................ 6

Factors Affecting Crop Losses Caused by Wild Dats ... 8 CONTROL OF WILD OATS .......................... 10

Agronomic Practices ...................... 10

Cultural Control ...................... 10

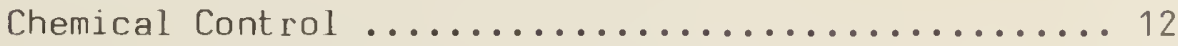

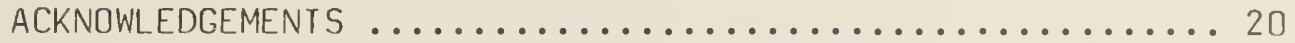





\section{INTRODUCTION}

Canada.

Wild oat is among the most common and troublesome weeds in western

Few weeds rival wild oat for its ability to survive and persist in cult $1-$ vated farmland. In addition wild oat excels in its capacity to compete with cereal and oilseed crops and cause substantial yield losses.

Most taxonomists agree that our species of wild oat (Avena fatua) originated in Asia Minor from Avena sterilis which gave rise to both the wild and tame oat species. Regardless of their point of origin, wild oats now exist around the world and are particularly abundant in regions with extensive agriculture such as in the prairie provinces.

Wild oat was introduced to the prairies in seed brought with the settlers during the immigration boom of the late 1800s. It spread quickly and by 1931, wild oats infested $85 \%$ of our cropland. Fifty years later, it still persists in the same areas, despite extensive knowledge of its biology and the availability of highly effective herbicides.

Wild oats consistently reduce yields in cereal, oilseed and special crops. In an attempt to avoid yield losses, it is estimated that farmers in Canada treat over $8 \mathrm{million}$ hectares of $\mathrm{l}$ and with wild oat herbicides costing \$90-100 million every year. Besides the direct losses to the farmer, there are also costs involved in transporting and cleaning grain. It is estimated that at least 6,000 car loads of dockage are transported to Vancouver and Thunder Bay every year. About 25\% of this dockage is calculated to be wild oat seed.

It is evident that wild oat is a serious and costly problem.

\section{SURVIVAL MECHANISMS}

A variety of survival mechanisms contribute to the ability of wild oats to persist in cultivated cropland. These mechanisms exist in the seed, the seedling and the mature plant.

\section{Do rmancy}

Dormancy is a mechanism which prevents germination even when seeds are exposed to favourable environmental conditions. Processes within the seeds themselves stop active growth of the embryo and thus restrict germination. Dormant wild oat seeds may remain viable in the soil for as lonq as seven years.

If a wild oat seed is dormant when shed it is sald to exhibit primary dormancy. This dormancy is gradually lost with time by a process known as afterripening. The rate of loss varies greatly between different strains of wild oats. Consequently, it is often very difficult to predict the degree of 
dormancy in any one population. In addition, the time required for seeds to afterripen or lose dormancy is greatly influenced by environmental conditions. In general warm, dry conditions promote afterripening while cool, moist conditions delay the process.

After primary dormancy has been lost, a further restriction in germination known as secondary dormancy, may be induced under unfavorable environmental conditions such as excess moisture and fluctuating temperatures. Therefore wild oat dormancy is complicated by the fact that it is not a constant state. Dormancy can disappear, then recur in the same seed depending on the environment. For example after harvest, when seeds are on or near the soil surface, warm dry weather conditions may cause a large percentage of the seeds to lose their dormancy. Moisture at this time could induce many of the seeds to grow providing that the temperature and soil factors are suitable. Even so, not all the seeds will germinate because loss of dormancy occurs at varying rates. During the early part of the next spring, dormancy can be reinduced in some of the seeds under conditions of excess moisture and low temperatures. Some of this dormancy may again be lost by subsequent drying as the soil is warmed. The seeds that remain dormant can be forced into a deeper state of dormancy by exposure to conditions suitable for germination followed by drying. Much of this dormancy may disappear again if summer conditions are hot and dry, but lack of moisture often prevents germination at this time. Precipitation combined with hot and humid conditions may return seeds to the dormant state.

Dormancy, in its varying forms, is an effective survival mechanism in that no particular set of conditions will break dormancy of the entire seed population in the soil. A residual population, small as it may be, survives to start new plants and produce more seed as conditions change.

\section{Germination}

Unlike with many other weeds, light has been found to inhibit germination of wild oats. Tests have shown that if seed is continually exposed to light, less than 10\% of the seeds will germinate. Seeds of wild oat have a built-in mechanism to assure burial in moist soil. The awns can unwind and twist under moist conditions to allow the seeds to work their way into the soil, where light intensity is low enough to permit germination.

The main flush of wild oat growth occurs early in the spring so that the early seeded crops are the most heavily infested. Although the cool, moist conditions at this time tend to promote maximum emergence, limited amounts of germination can occur throughout the growing season, under a variety of temperature and moisture conditions.

In the absence of other limiting factors, wild oat seeds will germinate readily over a fairly wide range of temperatures from 5 to $26^{\circ} \mathrm{C}$. However, maximum germination usually occurs at 15 to $26^{\circ} \mathrm{C}$.

Soil moisture has a pronounced effect on the emergence of wild oats. Germination is most rapid when soil moisture levels are slightly below field 
capacity although wild oats can also germinate at lower moisture levels. Germination usually takes place from shallow depths early in the season if molsture is adequate. As the surface soil dries, germination occurs at lower depths. Wild oats have been known to emerge from depths of $20 \mathrm{~cm}$ although most do not emerge from depths of more than 7.5 to $10 \mathrm{~cm}$.

Some wild oat seeds with small sprouts can withstand as much as seven days drying at $22^{\circ} \mathrm{C}$ with growth arrested. Resumption of growth occurs when they are moistened again. If rain occurs at seeding time, it gives the wild oat seeds that are ready to resume growth a faster start than the crop. Il also has the effect of making the seasonal growth of wild oats unpredictable.

\section{Physical St ructure}

Wild oats can emerge from greater depths in the soil than most cereals. The first internode or "mesocotyl" of wild oat has qreat powers of extension so that it can push the stem apex and surrounding leaf tissue up in the soil for a considerable distance. This action usually allows the first leaf to emerge with the protection of the coleoptile (the sheath surrounding the first leaf). The coleoptile, however, cannot elongate indefinitely and the seed can be so deep that the first leaf sometimes breaks through the coleoptile before it reaches the soil surface.

In wheat, barley and rye the first internode is very short and the base of the coleoptile remains close to the seed. Protection to the enclosed leaf is limited by the amount the coleoptile can elongate. Deep seeding, therefore, delays emergence and produces weak seedlings.

\section{Regrowth and Rerooting}

Small sections of wild oat seedlings, $2.5 \mathrm{~cm}$ in length, and containing the coleoptile node can become rerooted. If conditions are favorable, these sections may produce fully developed plants. Wild oat plants up to 32 days old that are damaged by cultivation can produce healthy plants if the nodes are buried and good growing conditions exist. Cultivation for control should be done when the wild oats are in the 2 to 3 -leaf stage.

Fortunately wild oat seedlings have one weakness. Until the seedlings reach the 3 to 4-leaf stage, they do not grow as rapidly as cereal crop seedlings. If the crop is able to get a good start on growth at this stage, wild oats lose some of their competitive advantage. However, once they reach the 3 to 4-leaf stage they develop extensive root systems and become very competitive with the crop.

\section{Early Maturity}

Wild oat is capable of producing mature seed in approximately 60 days, which is several weeks less than is required for the cultivated oat or any of the other cereals. Thus by the time cereal crops are ready to be harvested, many wild oat seeds have matured and been dispersed from the spikelets. The ease of shattering of the panicles and resulting dispersal of seed in the field also adds to their persistence. 

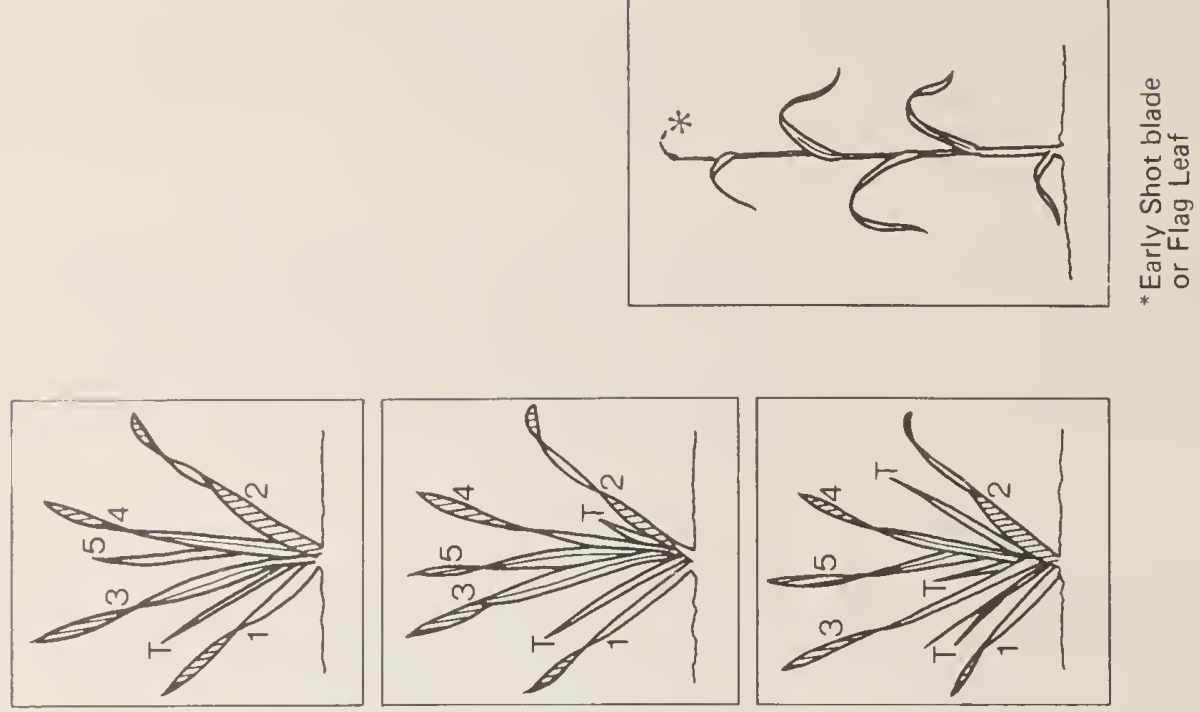

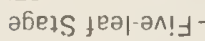
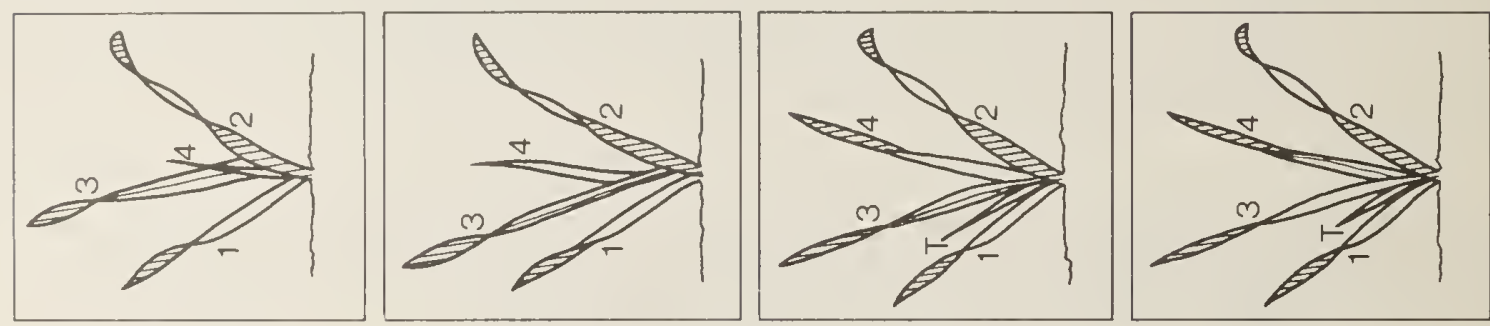

ว6eis teว-Anoy
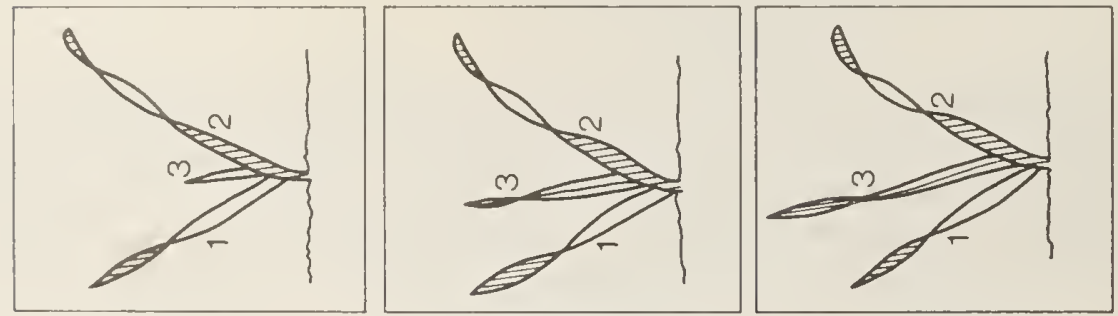

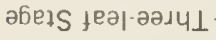
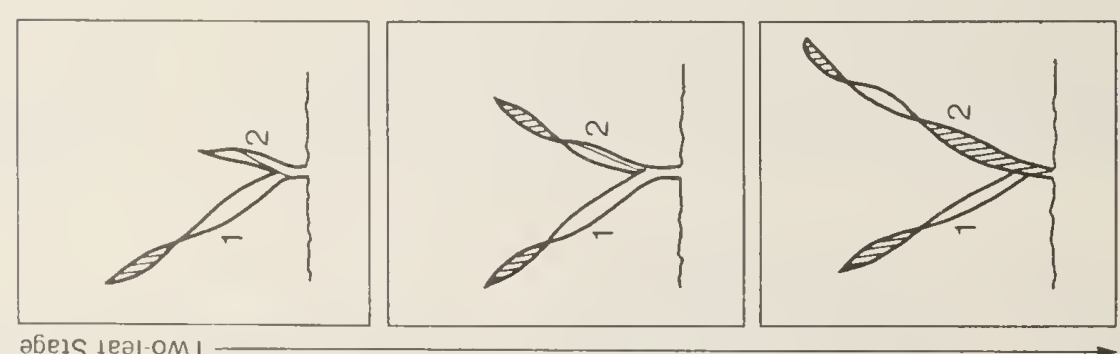

ә6eıs 」еㅏ-OMI

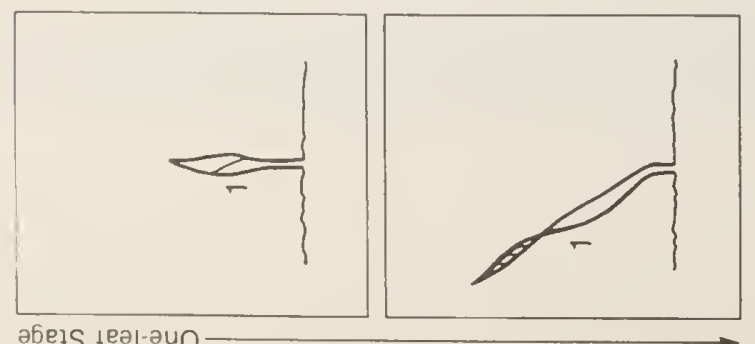

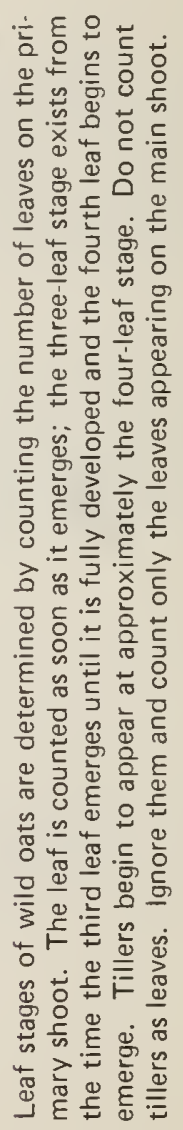




\section{WILD OAT IDENTIFICATION}

Identification of wild oat seedlings growing in wheat or barley is sometimes a problem. When viewed from above the first full leaf of the wild oat has a counter-clockwise iwist. Wheat and barley leaves curl clockwise.

The young leaves and sheaths of these species differ also. Barley has long, smooth auricles that clasp the stem; wheat has shorter, hairy auricles and the wild oat has no auricles. Also the leaf margins of wild oats have hairs.

Distinguishing barley from wild oat seedlings is easier than with wheat. Until some experience has been gained, identification should be confirmed by digging up the young plants. Loosen the soil around the seedlings, lift them out carefully, and identify the seeds attached to the shoots.
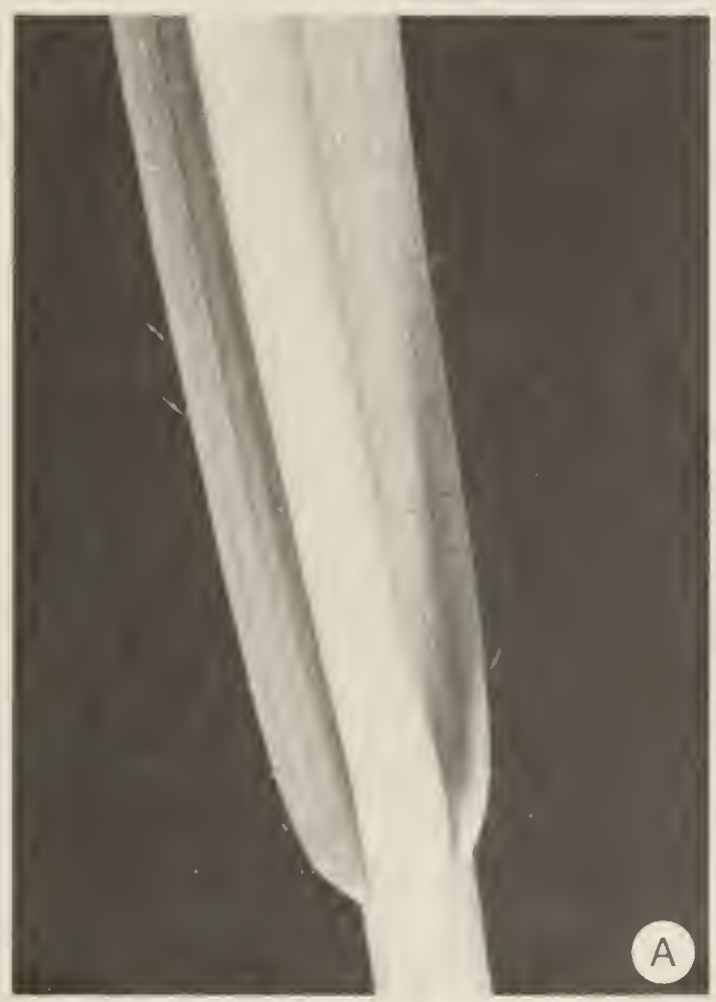

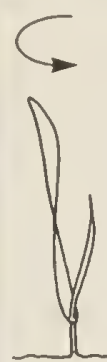

Wild Oats
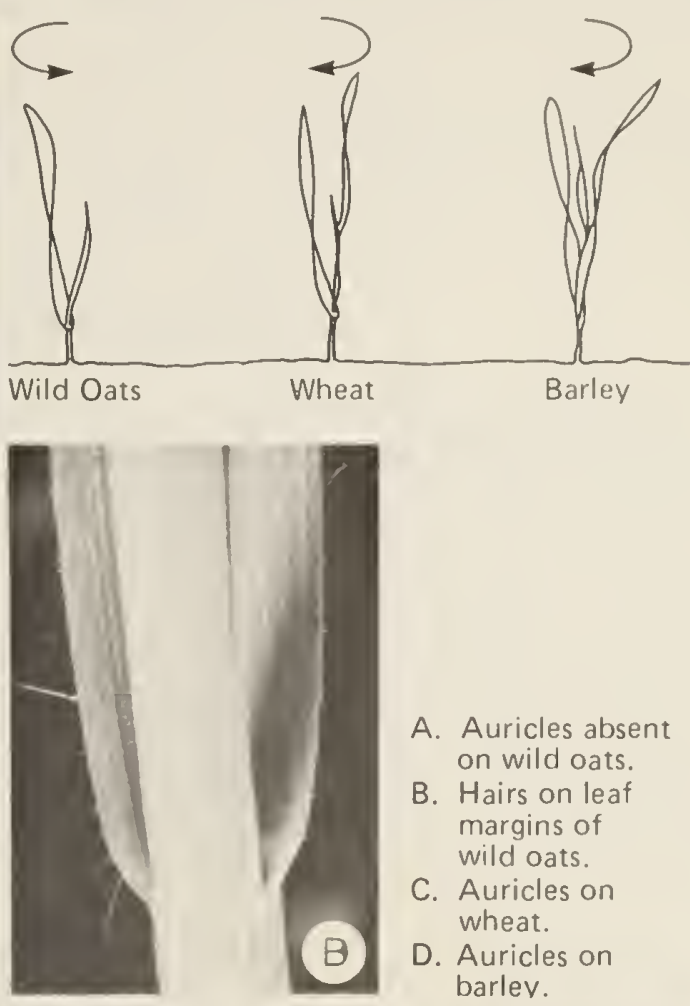

A. Auricles absent on wild oats.

B. Hairs on leaf margins of wild oats.

C. Auricles on wheat.

D. Auricles on barlev.

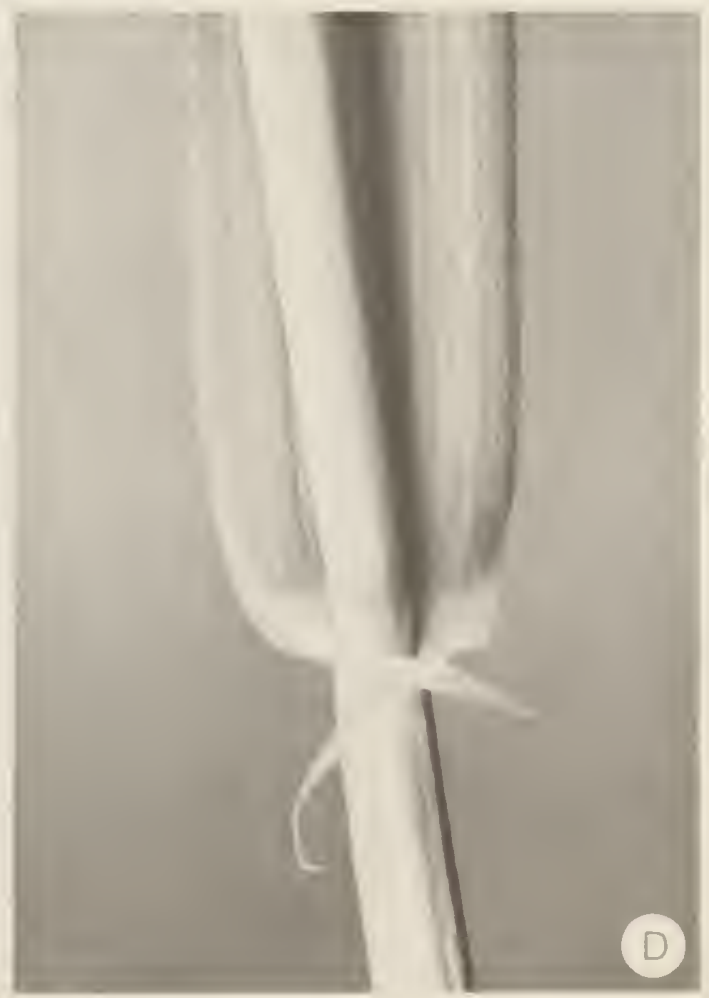




\section{Uneven Ripening}

Unlike cultivated crops, all of the seeds in a panicle of wild oat do not mature at the same time. Maturation is uneven so that seeds at the tip of the main axis of the panicle may ripen and fall to the ground before the seeds at the base are filled. Differences in maturity may also occur in an individual spikelet with primary seeds generally maturing before the secondary seeds.

In addition, wild oat seeds do not need to be mature to be viable. Some seeds are viable as early as four days after pollination. Consequently, if mowing is to be an effective control measure it is necessary to cut the wild oat plants soon after pollination.

\section{POTENTIAL LOSSES FROM WILD OATS}

In order to determine the need for control measures, some estimation of the numbers of wild oats growing in the field must be made. A short time spent in the field counting wild oats will help decide how much can be profitably invested in a control program.

Counts should be based on how the wild oats are distributed throughout the field. If the wild oats are growing more or less evenly over the field, it is suggested that counts be made at a minimum of 10 sites within the field. The level of accuracy in the estimate increases with the number of sites examined. If the wild oats are not evenly spread, it is advisable to take 10 counts in the heavily infested area and another 10 in the lightly infested area. These areas may have to be treated separately.

For the purpose of taking wild oat counts, a square metre quadrat can be made by bending a $3 \mathrm{~m}$ length of heavy wire at right angles at $1 \mathrm{~m}$ intervals. In situations where the wild oat population is very heavy, it may be more practical to use a quarter square metre quadrat and multiply the resulting number by 4 to yield a value per square metre. Counts per square metre are added and then divided by the number of sites sampled to obtain an average count.

The average number of wild oats per field obtained through $r$ andom counts can then be used to determine the potential yield losses in tonnes/hectare and in dollars (Table 1). Although it is difficult to put an exact figure on yield reduction, the data in Table 1 can be used to give a rough estimate of yield losses. For example, in wheat, if the density of wild oats $/ \mathrm{m}^{2}=20$, and the expected wheat yield $=2.4 \mathrm{t} / \mathrm{ha}$, then the expected yield loss $=0.36$ $\mathrm{t} / \mathrm{ha}$. If wheat is $\$ 217.96 /$ tonne ( $\mathrm{final}$ price 1980-81), then the dollar loss per hectare is $0.36 \times \$ 217.96=\$ 78.47 / \mathrm{ha}$. The data assume that the wild oats emerged at the same time as the crop and that they are distributed evenly throughout the field. If a preemergence herbicide is to be used, control decisions must be based on anticipated levels of wild oats, using the past history of the field as a guide.

These potential yield loss figures assume 100\% weed control. Unfortunately total control is rarely possible in farm fields because control measures 


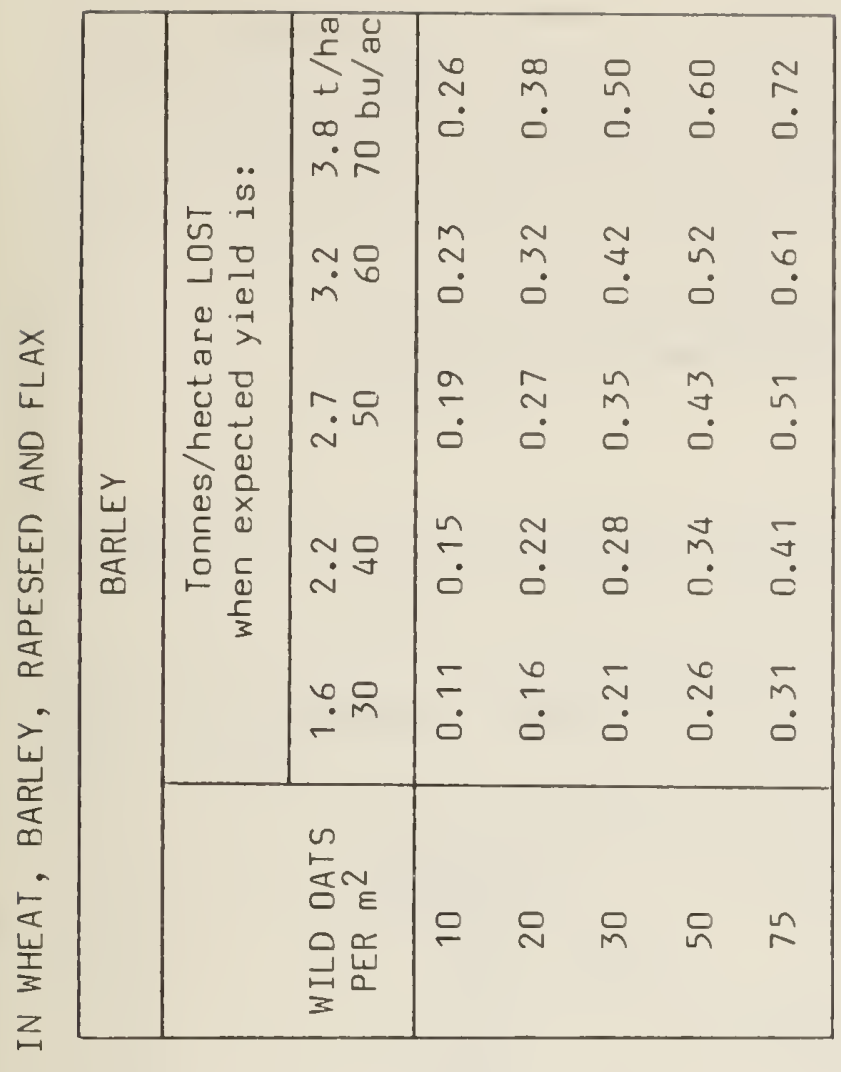

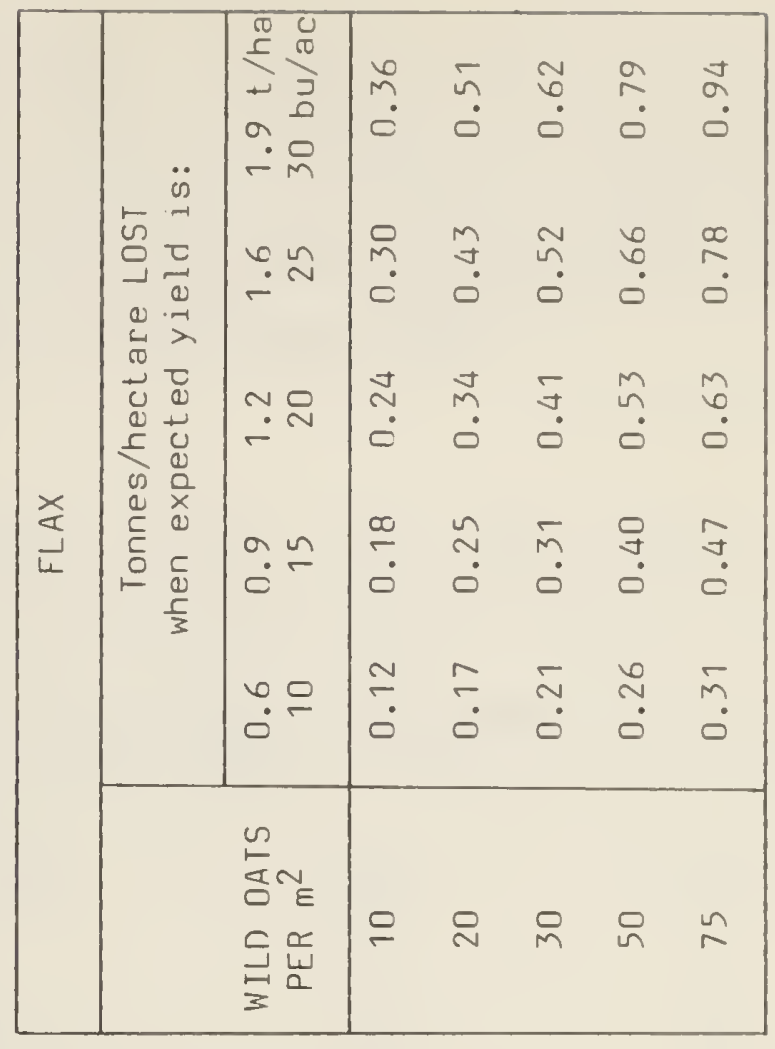

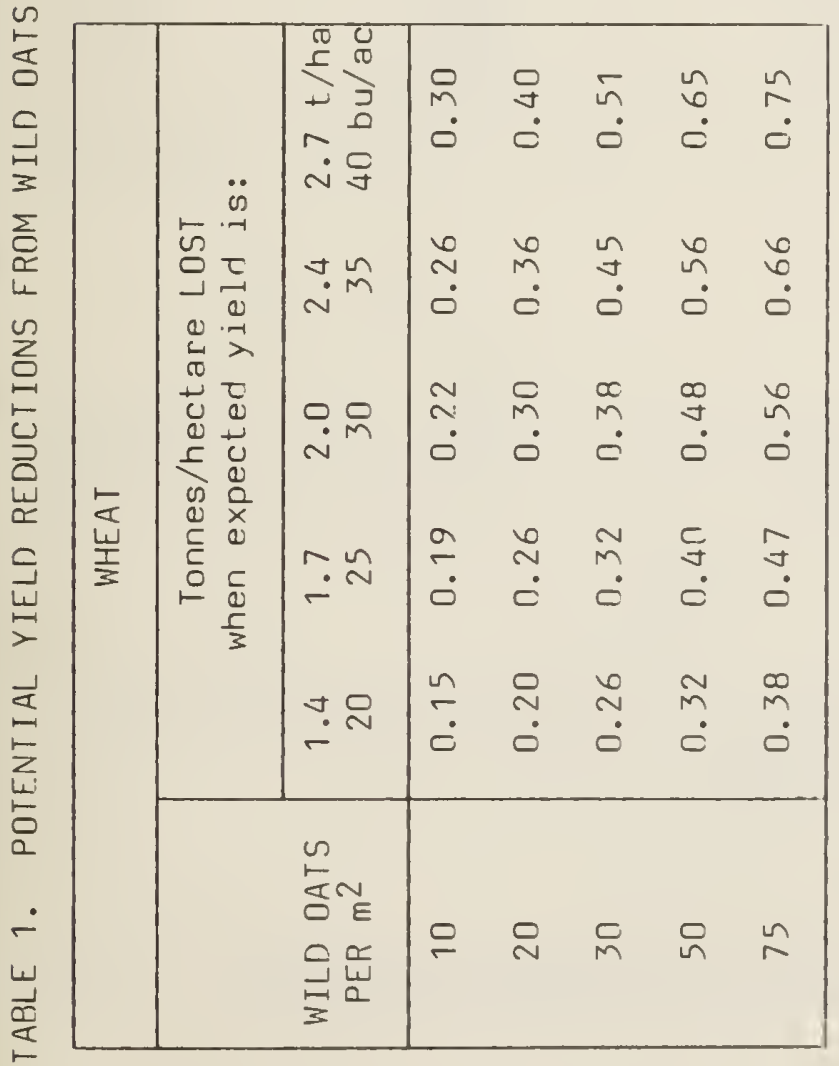

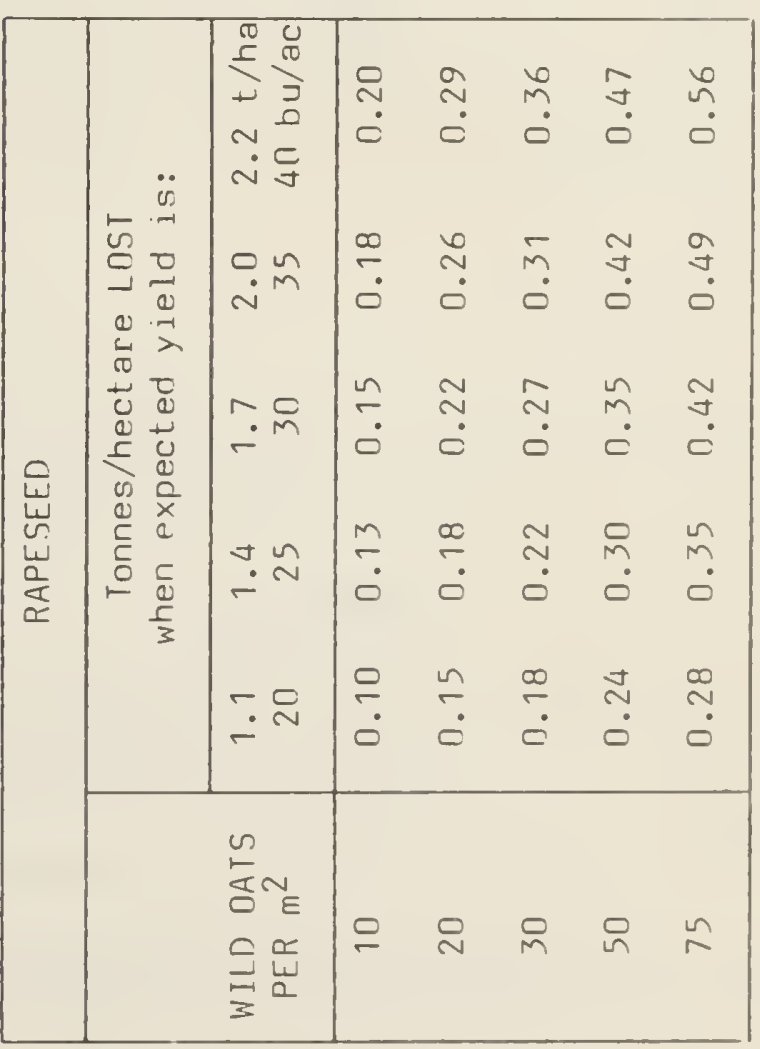


are not absolutely effective in every situation. Their effectiveness depends on how well they are applied, the growth stage, as well as soil and weather conditions at the time of application and the equipment used. Therefore the full amount of the potential yield or crop value may not be recovered. The yield reduction figures are useful only as a guide to assessing the potential crop losses caused by wild oats and as a means of determining what control measures are practical and economical.

\section{Factors Affecting Crop Losses Caused By Wild Dats}

\section{CROP SPECIES}

Barley is the most competitive crop to wild oats followed by rapeseed and wheat (Table 2). Flax, and some of the pulse crops like field peas and lentils, compete very poorly with wild oats.

TABIEE 2. PERCENTAGE LOSS IN YIELD WITH DIFFERENT DENSITIES OF WILD OATS IN WHEAT, BARLEY, RAPESEED, AND FLAX

\begin{tabular}{ccccc}
\hline WILD OATS & \multicolumn{4}{l}{ PERCENTAGE } \\
PER M & LSS & IN YIELDa & Y \\
\cline { 2 - 5 } & WHEAT & BARLEY & RAPESEED & FLAX \\
\hline 0 & 0 & 0 & 0 & 0 \\
10 & 10.7 & 7.3 & 8.0 & 19.0 \\
20 & 15.0 & 10.3 & 11.3 & 27.0 \\
30 & 18.7 & 12.7 & 14.0 & 33.0 \\
50 & 24.0 & 16.3 & 18.0 & 42.3 \\
75 & 28.3 & 19.3 & 21.3 & 50.3 \\
\hline
\end{tabular}

aThe weed-free yield of the crops was $2.0,1.6,1.9$ and 1.7 tonnes/ha, respectively.

FERT IL ITY LEVEL

Studies show that the higher the level of fertility in the soil, the greater the potential yield reduction from wild oat competition. It appears that wild oats benefit as much as the crop from fertilizer, particularly when nitrogen is broadcast on the soil surface.

\section{ENVIRONMENTAL CONDITIONS}

In general, wild oats are more tolerant than the crop to stress conditions such as drought. Consequently they may be able to maintain growth at the expense of the crop under these conditions.

\section{NUMBER OF WILD OATS PRESENT}

Ten wild oats per square metre in wheat can reduce yield by $11 \%$ while 75 wild oats in the same area would result in a $28 \%$ reduction (Table 2 ). 


\section{TIME OF EMERGENCE}

The amount of crop yield reduction depends on whether the wild oats emerge before, at the same time or after the crop. Although growth of wild oats is initially slow, they grow rapidly and develop extensive root systems once the 3 to 4-leaf stage is reached. Therefore, if they emerge before or at the same time as the crop, they have a chance to become firmly established as competitors for moisture and nutrients. But if wild oats emerge a few days to a week after the crop, their competitive ability and their influence on crop yields is qreatly reduced.

\section{TIME OF REMOVAL}

The earlier that wild oats are removed from the crop, the less chance they have of using up valuable moisture and nutrient reserves and lowering crop yield (Figure 1). For example, if wild oats emerge at the same time as the crop and are not removed until 30 days after emergence, reductions in yield of approximately $14 \%$ in barley, $15 \%$ in rapeseed, $22 \%$ in wheat and $35 \%$ in flax may öccur.

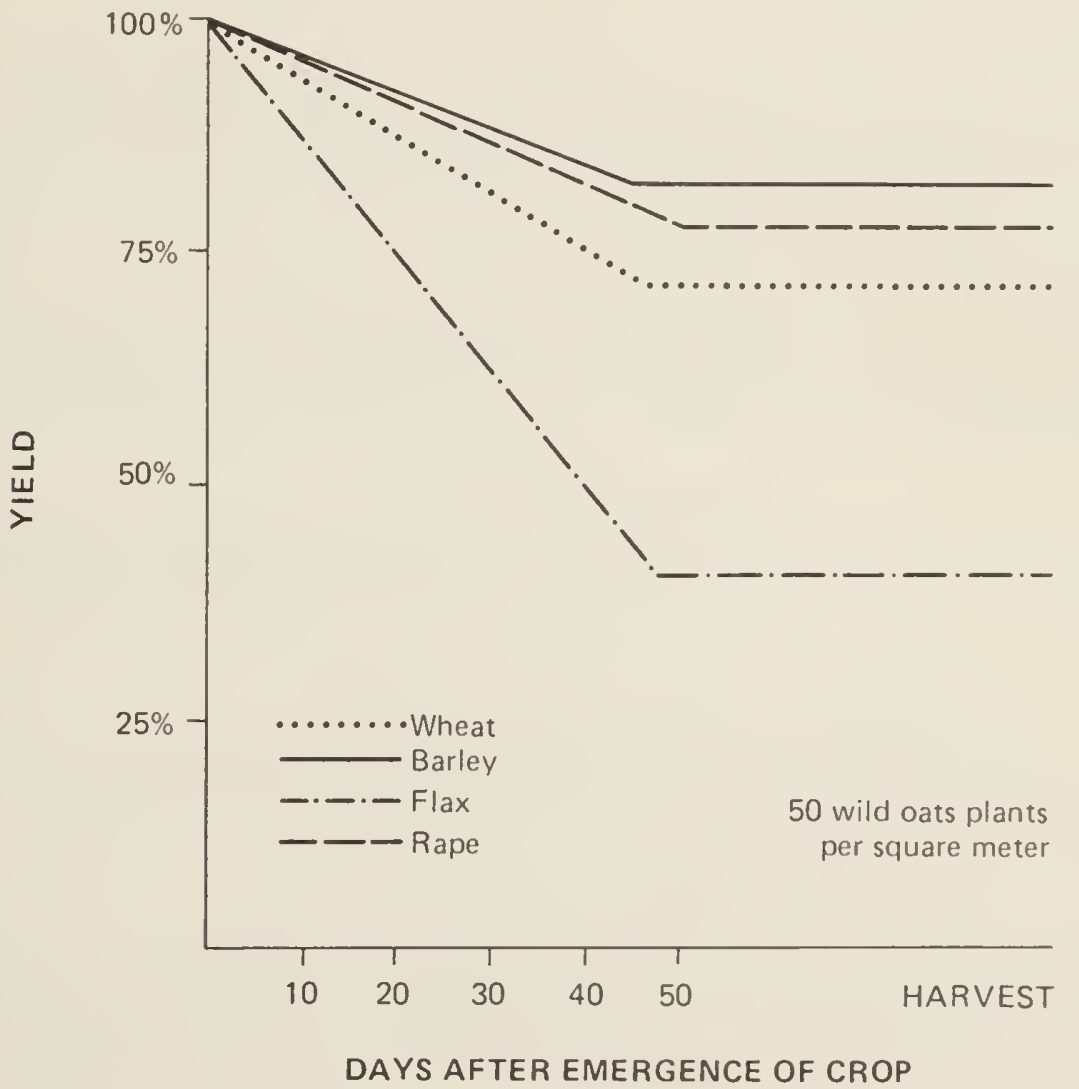

Figure 1. Effect of duration of wild oat competition on crop yield. 


\section{CONTROL OF WILD OATS}

Controlling wild oats thirty years ago was a much more difficult task than it is today. Farmers had limited means at their disposal: delayed seeding, cutting badly infested areas for greenfeed or sowing fields down to forage crops. Today farmers can utilize a variety of control measures such as agronomic practices that promote rapid germination and a good establishment of the crop stand as well as cultural and chemical control methods. While wild oats are almost impossible to eliminate completely, they can be kept to a low level in cereal, oilseed and specialty crops through the use of a combination of these methods.

\section{Agronomic Practices}

\section{USE CLEAN SEED}

Seed which contains even a few wild oat seeds is enough to maintain a moderate level of infestation. It is imperative that seed be completely free of wild oats or the qrower ends up paying for herbicide to control the problem and at the same time pays for seed that perpetuates the problem.

\section{ENCOURAGE RAPID CROP GERMINATION}

The seedbed should be level and firm so that seed can be uniformly planted at shallow depths. Recommended seeding rates should be used because in general thin crop stands do not compete well with wild oats.

USE CULTIVARS WELL SUITED TD THE AREA

Cultivars that are well adapted to the area's soil type, moisture availability and frost-free days compete more successfully with weeds than varieties that are marginal for the area.

\section{Cultural Control}

Cultural control methods need to be selected on an individual field basis and according to:

* crop rotations

* soil types and moisture levels

* summerfallow and cultivation practices

* size and distribution pattern of the wild oat population

\section{DELAYED SEEDING}

Delayed seeding and the use of an early maturing crop is often considered to be one of the best methods of cultural control. However the data from an eight year study indicate that delayed seeding may be an uneconomical method of controlling wild oats (Table 3). The reduction in yield and the accompanying lower grades from the later seeded crops consistently resulted in high sacrifices in dollar value. The higher returns from early seeding would more than compensate for the cost of a wild oat herbicide. 
TABLE 3. AVERAGE INCOME ${ }^{-}$FROM THREE DATES OF SEEDING

\begin{tabular}{llccr}
\hline \multirow{2}{*}{ CROP } & \multicolumn{2}{c}{ SEEDING DATE } & YIELD & LOSS \\
\cline { 4 - 5 } Wheat & Early (normal date) & 3.14 & T/ha & \$/ha \\
\hline & Middle (10 day delay) & 3.06 & 429 & 0 \\
& Late (20 day delay) & 2.65 & 410 & 19 \\
Barley & Early & & 336 & 33 \\
& Middle & 3.44 & 382 & 0 \\
& Late & 3.01 & 333 & 50 \\
\hline
\end{tabular}

aBased on average final wheat board price (1975-78)

bvalues rounded to the nearest dollar

But delayed seeding is not without some practical value. It can be successfully used in fields where a serious wild oat infestation exists. By seeding these fields last, at least one flush of wild oats can be controlled by cult 1vation. If some portions are still infested, these can be spot treated with a postemergence herbicide or cut for qreenfeed.

POSTSEEDING CULTIVATION

It is possible to control wild oats by postseeding cultivation if the following conditions are met. First of all it is necessary to seed the crop a little deeper than usual with the packing operation omitted to avold surface soil compaction. The majority of the wild oats must emeroe ahead of the crop and the soil surface should he dry and free from excess trash. The cultivation should be done before the nrain sprouts are $20 \mathrm{~mm}$ long. In other circumstances there is a risk that cultivation could cause more damage to the crop than the wild oats.

A rod weeder is recommended for this operation but a cable weeder or flexible harrows may also he used. The tillane operation should be shallow and done with care to reduce possible crop injury.

\section{GREENFEED CROPS}

Greenfeed crops, such as tame oats, can be used to help grow out wild oats. But to prevent seed production, the crop should be cut just as the panicles of the wild oats start to emerae from the sheath. Wild oat plants cut four days after pollination can still produce a few seeds that will qerminate. To prevent reqrowth the field should be tilled and summerfallowed for the rest of the season.

\section{FALL-SEEDED CROPS}

Fall rye and winter wheat are a practical alternative to check wild oats in areas where these crops are adapted. Since fall-seeded crops beqin qrowth early in the spring, they tend to smother the wild oats which aerminate later. In qeneral, rye is more vigorous and compet 1 tive than winter wheat. 


\section{BURNING}

Burning straw or stubble for control of wild oats is not recommended. Fire may kill some wild oat seeds lying on the soil surface, but in general burning does not result in a high degree of control. Furthermore, it increases the risk of soil erosion, decreases valuable snow cover and destroys a beneficial source of oraanic matter.

\section{FALL TILLAGE}

The effectiveness of fall tillage depends on the amount of secondary dormancy in the seed which in turn depends on the soil and climatic conditions. If the seeds mature under cool, moist conditions, there is a hiaher deqree of dormancy than in seeds that mature under warm, dry conditions. When there is little seed dormancy, the seeds will afterripen and germinate quite quickly. Under these conditions a liaht fall tillage, which buries the surface seeds and encourages germination and subsequent killing by frost, may be of value. However, the increased germination following a tillage operation in the fall does not necessarily indicate that fewer seeds will germinate in spring since the process also serves to uncover and expose seeds already in the soil.

\section{SUMMERFALLOW}

The practice of summerfallowing can be used to reduce the wild oat seed population in the soil, if it fits into crop rotation plans. The loss in crop production for a year, increased risk of soil erosion and contribution to increasing salinity are factors which may discourage the practice of fallowing.

\section{CROP ROTATION}

Crop rotations can be useful in a control program. Experience has shown that rotations with cereal crops alone tend to become heavily infested with wild oats. Alternating with a broadleaf crop such as rapeseed, flax or lentils provides an opportunity for the use of alternative herbicides.

\section{Chemical Control}

Herbicides for the control of wild oats have been in use since the early 1960s. Only two products (diallate and barban) were available at that time with severe limitations on crops which could be treated. Now about a dozen different wild oat herbicides are available for use on a variety of crops and the areas in western Canada treated with these herbicides have arown extensively (Table 4). Regardless of whether they are soil-incorporated or sprayed on the foliage, all of these products are effective only if applied correctly. Therefore calibration, cleaning and maintenance of spray equipment is extremely important to assure uniform and complete coverage. Weather conditions before, during and after application also play an important part in how effectively these products perform.

The following information includes the mode of action of each wild oat 
herbicide as well as factors affecting its performance. For specific information on rates and methods of application, please refer to provincial chemical weed control bulletins or the label on the container.

TABLE 4. SUMMARY OF WILD OAT HERBICIDE USE IN THE PRAIRIE PROVINCFS: 1967-1981

\begin{tabular}{lrr}
\hline YEAR & HECTARES & ACRES \\
\hline 1967 & 520,000 & $1,300,000$ \\
1969 & 550,000 & $1,375,000$ \\
1971 & 572,000 & $1,430,000$ \\
1973 & $1,633,200$ & $4,083,000$ \\
1975 & $3,693,600$ & $9,234,000$ \\
1977 & $5,288,000$ & $13,220,000$ \\
1979 & $7,949,920$ & $19,874,800$ \\
1981 & $7,195,100$ & $17,987,750$ \\
\hline
\end{tabular}

\section{PREEMERGENCE HERRICIDES}

Avadex $B W$ (triallate)

Monsanto Canada Inc.

FORMULATIONS Emulsifiable concentrate, granular.

TOLFRANT CROPS Spring and durum wheat, barley, flax, rapeseed, mustard, peas, sugarbeets.

MODE OF ACIION Triallate is taken up through the underaround wild oat shoot and not by the roots. Seedlinas that germinate in treated soil are killed quite rapidly through inhibition of cell division and elongation. The amount of growth prior to death increases as the germination depth below the treated layer increases. For example, a wild oat seedling emerging from a depth of 15 $\mathrm{cm}$ may reach a height of more than $5 \mathrm{~cm}$ before it dies, whereas seedlinos germinating in the treated layer will not emerae.

SYMPTOMS The major effects on wild oats are evident before they emerqe through the soil surface. Removal of the top 2-3 cm of soil, one to two weeks following treatment will expose white to yellow coloured shoots with decayed, pinched tips. Seedlings which emerqe may show more aradual cessation of growth with the leaves becoming brittle and bluish-qreen in colour.

CONDITINNS WHICH AFFECT PERFORMANCE 1. The liquid formulation is volatile and should be incorporated immediately after application or substantial amounts of triallate will evaporate from the soil surface.

2. Both liouid and granular formulations need moisture for activation. When triallate is applied to very dry soil and rain does not occur until several weeks after seedino, wild oats may escape the treatment. Conversely, excessive moisture within two weeks after 
application may enhance the herbicidal activity and increase the hazard of injury to wheat. Soil temperatures must be greater than $5^{\circ} \mathrm{C}$ to activate triallate.

3. On fields where erosion is a threat, spring application or the use of a post emergence product is preferred over a fall treatment with triallate.

PERSISTENCE The main losses of triallate are by volatility and biological degradation from the treated soils. Both these processes are affected by soil conditions and in general the warmer and wetter the soil, the areater the loss. Losses from dry soils tend to be minimal. When triallate is applied in late fall, 20-75\% may be present in the spring.

Eptam, Eradicane (EPTC)

Stauffer Chemicals

FORMULATIONS Eptam 8-E and Eradicane 8-E (emulsifiable concentrate), Eptam 10G (qranular).

TOLERANT CROPS Eptam - flax, sunflowers, field beans, sugarbeets; Eradicane corn.

MODE OF ACTION EPTC is absorbed by the underground shoot and root of the germinating wild oat seedling. The herbicide interferes with cell division in the growing point which causes a disruption in overall plant growth.

SYMPTOMS Often there will be no visible signs of injury above the soil surface. However wild oat seedlings recovered from the soil will show swelling of the underground shoot and malformed roots. Wild oat plants that emerge will have distorted leaves that fail to come out of the coleoptile sheath in a normal manner.

CONDITIONS WHICH AFFECT PERFORMANCE 1. EPTC is volatile and will be lost rapidly, especially if applied to a wet soil surface. Therefore, incorporation should be within minutes of application and preferably in the same operation.

2. EPTC will not be as effective if applied to moist or trashy soil surfaces.

3. A minimum soil temperature of $8^{\circ} \mathrm{C}$ is required for activation of EPTC.

PERSISTENCE EPTC usually does not persist in the soil beyond the end of the orowing season.

Treflan (trifluralin)

$\overline{\text { Elanco Products }}$

FORMULATIONS Emulsifiable concentrate, granular. 
TOLERANT CROPS Rapeseed, mustard, flax, sunflowers, peas, field beans, fababeans, soybeans.

MODE OF ACTION Trifluralin is readily absorbed by the root and to a lesser extent, the underground shoot of wild oats, but the chemical does not move freely within the remainder of the plant. Therefore the primary effect of this herbicide is to inhibit root qrowth of wild oats during qermination through interference with the cell division process.

SYMPTOMS Many wild oat seedlings are killed as they germinate. However those wild oats qerminatina just prior to application of trifluralin may escape its initial killing action. In these plants the roots usually become thickened and stubby causing stunting of the wild oats and eventual death.

CONDITIONS WHICH AFFECT PERFORMANCE 1. Incorporation to a depth of $7.5-10 \mathrm{~cm}$ within eight hours after spraying is essential for optimum performance of trifluralin.

2. Although trifluralin needs only a limited amount of moisture for activation, prolonged dry spells after treatment and incorporation in the spring can reduce its effectiveness.

3. The amount of organic matter in the soil affects the activity of trifluralin. Higher rates of the herbicide are required in soils with approximately $9 \%$ organic matter and it is not recommended for use on peat or muck soils.

4. The granular formulation is best suited for use under trashy conditions and is recommended for fall application only. If the soil is hard or the trash cover is very heavy, precultivation is necessary to ensure adequate mixing of the granules in the soil.

5. When applying the liquid formulation of trifluralin to stubble fields, crop residues should be chopped and thoroughly mixed into the soil to a depth of $7.5-10 \mathrm{~cm}$.

PERSISTENCE Trifluralin is lost from treated soils by volatility and biological degradation. Carry-over to the next year is dependent on soil conditions but is generally between 15 and $30 \%$.

\section{INCORPORATION OF SOIL-APPLIED HERBICIDES}

Proper incorporation is essential for good wild oat control when using soil-applied herbicides. The type of incorporation equipment used depends on the condition of the soil and the depth of incorporation desired. As a general rule, if the soil is loose and trash-free and the herbicide used requires a shallow depth of incorporation (Avadex BW), harrows alone or a shallow discing operation followed by harrowing is sufficient. But if the soil is cloddy, trashy or in stubble and a deeper incorporation is needed (Eptam, Treflan), the use of a discer or cultivator is recommended. 
Studies have revealed that harrows give the most uniform shallow incorporation while disc-type implements usually provide more uniform deeper incorporation. Cultivators, even when followed by harrowing, do not give as uniform an incorporation as the discers. Regardless of the implement used, speeds in excess of $8 \mathrm{~km} / \mathrm{h}$ should be avoided because of the increased risk of soil erosion from excessive pulverization and trash destruction.

\section{POSTEMERGENCE HERBICIDES}

Asulox F (asulam)

May \& Baker Canada Inc.

FORMULATION Solution.

\section{TOLERANT CROPS Flax.}

MODE OF ACTION Asulam is a systemic herbicide which is taken up by the leaves of wild oats and then translocated to other parts of the plant. It inhibits the process of cell division in the growing point and therefore the most noticeable effects occur in new growth.

SYMPTOMS Wild oats should start to turn yellow about one week after application. Growing points are killed within 1-2 weeks but mature leaves present at spraying age slowly. Yellowing (chlorosis) is followed by stunting and finally death of the plant. Wild oats which are not at the recommended stage or which emerged after spraying will be unaffected.

CONDITIONS WHICH AFFECT PERFORMANCE 1. The crop should not be sprayed with asulam if it is under stress because of drought or hot, humid weather.

2. Rainfall within six hours of application or spraying when the leaves are wet may adversely affect activity of asulam.

PERSISTENCE Asulam does not persist in the soil for long periods of time under conditions that favour microbial breakdown and there is usually no carry-over to the next crop year.

Avenge (difenzoquat)

Cyanamid Canada Inc.

FORMULATION Solution.

TOLERANT CROPS Barley (all varieties), wheat (Neepawa, Glenlea, Chester, Selkirk, Macoun), canary grass.

MODE OF ACTION When sprayed on leaves, difenzoquat moves throughout the leaf causing death, but there is no movement out of the leaf. When the herbicide enters below the growing point, it moves rapidly, killing the vital growing part of the wild oats. Since difenzoquat is not very mobile within the plant, 
good spray coverage is essential to ensure the herbicide covers all leaves.

SYMPTOMS Growth of wild oats is stunted which allows the crop to eliminate the weed through competition. Obvious sians of wild oat death may not be seen until three or four weeks after spraying but the competitive effect of these plants will have been reduced.

CONDITIONS WHICH AFFECT PERFORMANCE 1. The herbicide is very water soluble. If applied when plants are wet, or within six hours of rainfall, efficacy may be reduced.

frost is predicted the evening of spraying.

2. It is best to avoid application if

3. Under cool weather conditions or high humidity, most barley varieties may show some initial burning on lower leaves after spraying. However this symptom will soon disappear and yields are not affected.

4. The rate of difenzoquat required for control is related to the density of the wild oat infestation. Strong crop competition will improve the results of using the herbicide.

PERSISTENCE Soil residues are not considered a problem because the chemical is strongly adsorbed onto soil particles.

Carbyne (barban)

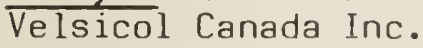

Wypout, Wypout 250 (barban)

Uniroyal Chemical

FORMULATION Emulsifiable concentrate.

TOLERANT CROPS Sprina and durum wheat, barley, flax, rapeseed, mustard, sunflowers, fababeans, peas, lentils, sugarbeets, various forage crops.

MODE OF ACIION Barban is taken up through the leaf but is not readily moved throughout the plant. Therefore it is important that spray droplets are aimed toward the crown or base of the wild oat plant where the inhibition of cell division in the growing point causes stunting and death.

SYMPTOMS When properly sprayed, wild oat seedlinos will stop growth within 24 hours and slowly change colour from a bright qreen to a dark bluish-qreen colour. Five to ten days after spraying the base of the seedlina will become enlarqed and swollen.

CONDITIONS WHICH AFFECT PERFORMANCE 1. Barban will qive better coverage and more effective wild oat control when the spray boom is approximately $30 \mathrm{~cm}$ above the crop, the nozzles are turned forward at a $45^{\circ}$ angle and a hiqh spray pressure $(310 \mathrm{kPa})$ is used. 
2. Barban does not control wild oats which have passed the 2-leaf stage and therefore timing is critical. Crop injury may occur if sprayed earlier or later than recommended.

3. Barban should not be applied when the crop is wet with dew or rain although rain occurring 15 minutes after application will not reduce the activity of the herbicide.

spring wheat variety, Park.

4. Wypout 250 should not be used on the

PERSISTENCE Under normal conditions, microbial breakdown of barban in soil is falrly rapid. Only trace amounts of barban can be detected after 3 weeks in most soils.

Hoe-Grass (diclofop methyl)

Hoechst Canada Inc.

FORMULATION Emulsifiable concentrate.

TOLERANT CROPS Spring, durum and winter wheat, barley (not all varieties), rye, triticale, flax, rapeseed, mustard, peas, lentils, field beans, fababeans, soybeans, buckwheat, sunflowers, sugarbeets, various forage species.

MODE OF ACTION Diclofop methyl possesses contact as well as systemic action with uptake primarily through the leaves. However the major site of action of diclofop methyl is the qrowing point so it is desirable that the herbicide be applied near the crown or base of the wild oats to obtain optimum kill.

SYMPTOMS Affected plants appear chlorotic 2-3 days after application. Yellowing of the plant deepens, uptake of nutrients and water from the soil halts and plant qrowth ceases. Within 10-14 days the treated wild oats will be dead.

CONDITIONS WHICH AFFECT PERFORMANCE 1. Application within one hour of rain may decrease performance.

2. Better coverage and subsequent control of wild oats by diclofop methyl will occur when nozzles are tilted $45^{\circ}$ forward.

3. Application during periods of drought and/or high temperatures above $28^{\circ} \mathrm{C}$ will result in reduced control.

4. Barley varieties, Klages, Betzes or Norbert, may be subject to phytotoxicity when treated with diclofop methyl.

PERSISTENCE Diclofop methyl is broken down fairly rapidly in the soil by microorganisms with less than $15 \%$ carry-over to the next crop year. 
Mataven ( $f$ lamprop methyl)

Shell Canada Ltd.

FORMULATION Emulsifiable concentrate.

TOLERANT CROPS Spring, durum and winter wheat, triticale, canary grass, var1ous forage species.

MODE OF ACTION Flamprop methyl is a systemic herbicide which enters the wild oats through the leaves and is transported from the leaves to the qrowina point in the stem. Cell division and elongation are impaired, thus affecting development of the entire plant.

SYMPTOMS Wild oats are either killed or stunted to the extent that they cannot compete with the crop.

CONDITIONS WHICH AFFECT PERFORMANCE 1. Best results will probably be obtained when the majority of the wild oats are at the 4-leaf staqe. Wild oats with less than three leaves at the time of spraying may not be controlled.

tion will reduce wild oat control.

2. Rainfall within two hours of applica-

3. Selkirk wheat has been found to be

sensitive to flamprop methyl.

PERSISTENCE Residues of flamprop methyl ranging from 15-30\% may be expected to persist in the soil the year following application.

\section{TANK MIXING WILD OAT HERBICIDES}

Tank mixing of herbicides is an application technique used to control a wide range of weeds by mixing two or more products in a sprayer tank. The main problems encountered when herbicides are incorrectly tank mixed involve reduced weed control, possible crop injury, or the formation of improper mixes that may cloa the sprayer.

When wild oat herbicides are mixed with herbicides for control of broadleaf weeds a partial loss of activity on wild oats is common. A loss of $5-10 \%$ in wild oat control is usually more costly than a second sprayina of the field with the broadleaf herbicide. Some herbicides can reduce wild oat control if applied within a few days of the wild oat herbicides. Refer to product labels and provincial weed control guides for additional details. Where no specific interval between application of the wild oat herbicides and other herbicides is recommended, an interval of at least four days should be allowed between the separate applications. 
TABLE 5. REGISTERED WILD OAT HERBICIDE TANK MIXES

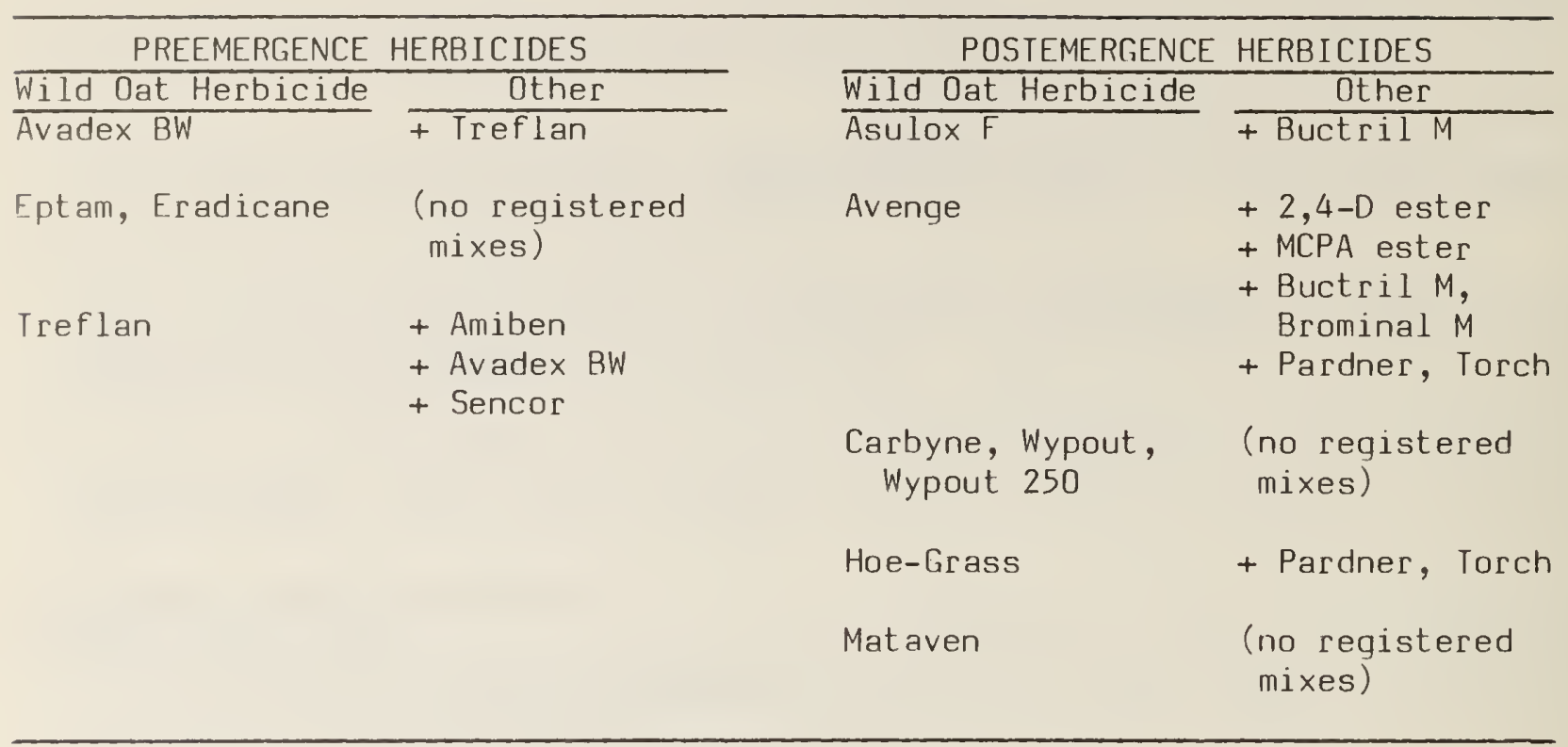

\section{ACKNOWLEDGEMENTS}

Research on the various herbicides was carried out by Agriculture Canada Research Station personnel in Western Canada, the Universities of Alberta, Saskatchewan, and Manitoba and the chemical companies concerned. Publication of the bulletin was sponsored by the Wild Oat Action Committee. The assistance of J. Dueck, J.R. Hay, D.I. Donaghy, W. Yarish and J.D. Banting in preparing this manuscript is also acknowledged. 


\section{CONVERSION FACTORS}

Approximate

conversion

Metric units

factors

Results in

LINEAR

millimetre $(\mathrm{mm})$

$\times 0.04$

$\times 0.39$

$\times 3.28$

metre $(\mathrm{m})$

$\times 062$

inch

inch

feet

kilometre $(\mathrm{km})$

mile

\section{AREA}

square centimetre $\left(\mathrm{cm}^{2}\right)$

square inch

square metre $\left(\mathrm{m}^{2}\right)$

$\times 1.2$

$\times 039$

square kilometre $\left(\mathrm{km}^{2}\right)$

$\times 2.5$

square yards

hectare (ha)

square mile

acres

\section{VOLUME}

cubic centimetre $\left(\mathrm{cm}^{3}\right)$

cubic inch cubic feet cubic metre $\left(\mathrm{m}^{3}\right)$

cubic yards

\section{CAPACITY}

litre (L)

cubic foot

gallons

bushels

\section{WEIGHT}

gram (g)

kilogram (kg)

tonne (t)

\section{AGRICULTURAL}

litres per hectare ( $\mathrm{L} / \mathrm{ha}$ ) 



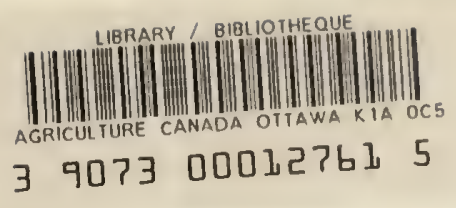

$\begin{array}{ll}630.72 & \text { Bubar, C. J. } \\ \text { C759 Growth habit and control of } \\ \text { C } 83-1 \mathrm{E} & \text { wild oats } \\ \text { OOAg } & \\ \text { C. } 3 & \end{array}$ 
